A 207

\title{
航空レーザ計測でみる都市の姿
}

藤田一郎(神戸大学), 中谷 剛 ${ }^{\circ}$ (アジア航測(株))

山本一浩(国交省近畿地整福井河川国道事務所)

\section{Appearance of city by Aerial-Laser-Survey}

\author{
Ichiro FUJITA, Tsuyoshi NAKATANI and Kazuhiro YAMAMOTO
}

\begin{abstract}
The aerial laser survey is the advanced technology of measurement of altitude by means of laser irradiation device installed in the aircraft. The accuracy of altitude measured by laser is $\pm 10 \mathrm{~cm}$ in horizontal, and $\pm 15 \mathrm{~cm}$ in vertical respectively. In this paper, by using aerial laser survey data, space occupation ratio was shown as an example of visualization of appearance of city. Space occupation ratio was found to be corresponding to the land use, such as residential area was high space occupation ratio and river and main roads were low. It was shown through the example that the appearance of the city can be made visible by the expression of statistical characteristics reduced by making full use of the original laser data.
\end{abstract}

Keywords: Aerial-Laser-Survey, 3 D-random-Data, Prevention of Disaster

\section{1. 緒 論}

航空レーザ計測とは、航空機に搭載したレーザ照射装 置から近赤外レーザ光線を地上に発射し、反射の時間遅 れからその地点の標高を計測する技術である。地上に設 置された GPS と航空機に搭載された GPS 及び姿勢制御 装置 (IMU) により、水平精度 $\pm 10 \mathrm{~cm}$ 、垂直精度 $\pm 15 \mathrm{~cm}$ で地表面の高さ情報を取得できる。

本研究では、都市の特徵を可視化した一例として、航 空レーザ計測によって得られた 3 次元点群データから算 出した都市の空間占有率（標高別地物占有率）について 述べる。また、航空レーザ計測の防災面への利用につい て報告する。

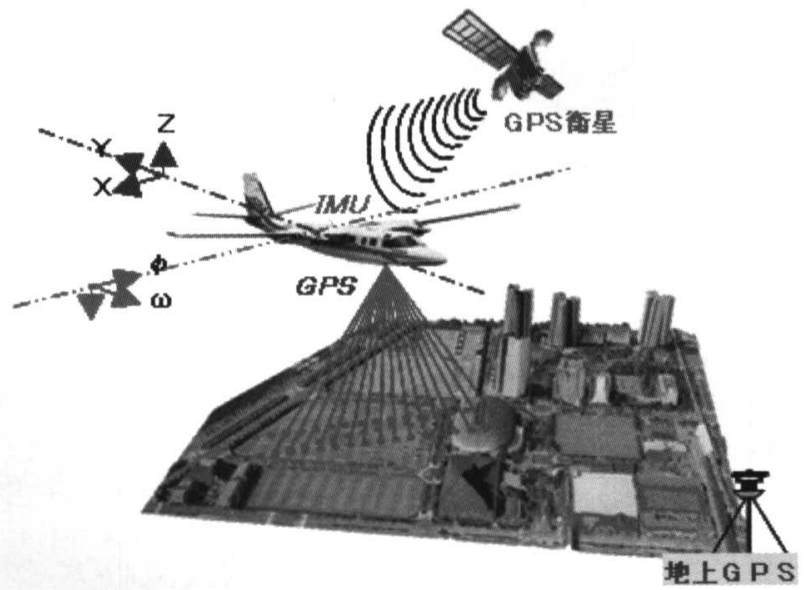

Fig. 1 Aerial-Laser-Survey

\section{2. データ処理}

\section{1 オリジナルデータ}

最新の航空レーザ計測装置では、 $100,000 \mathrm{~Hz}$ （1秒間 に 10 万発) でレーザ照射が可能で、 $2 \mathrm{~m}$ に一点程度の水 平平均密度で広範囲な地表面デー夕を取得できる。航空 レーザ計測で取得されるオリジナルデータは座標値を持 つランダムデータであり、これらに各種の情報処理を施 すことで地盤デー夕(DEM)、地表面データ (DSM)等へ の加工ができる。
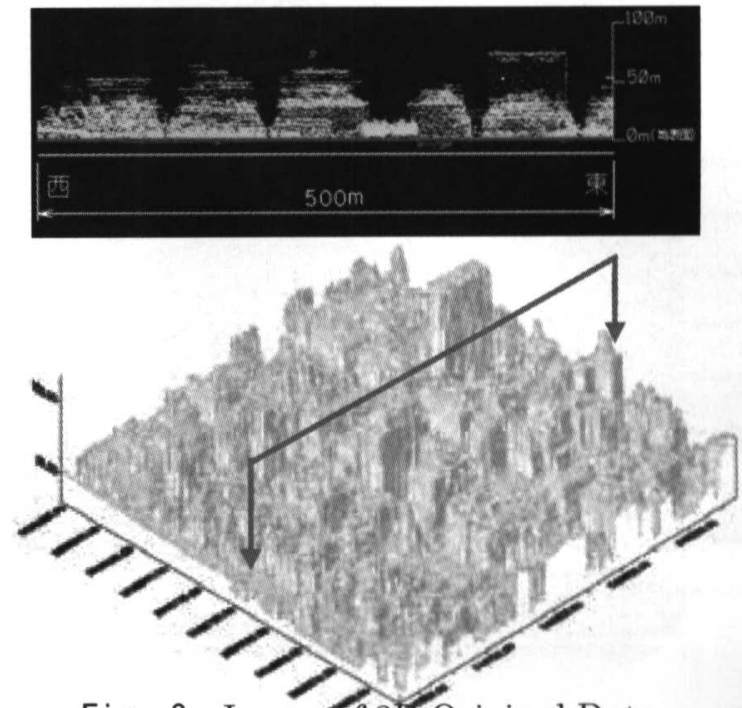

Fig. 2 Image of 31 Original Data 


\section{$2.2 \mathrm{DEM}$ と DSM データ}

オリジナルデータから地盤面データとその上の構造物 （地物）デー夕を情報処理することができる。前者を DEM (Degital Elevation Model)、後者を DSM (Degital Surface Model) と言う。Fig. 3 にDEM とDSM のイメ ージを示した。青色が地盤面で黄色から赤色に着色され た部分が地物（ビル群）である。

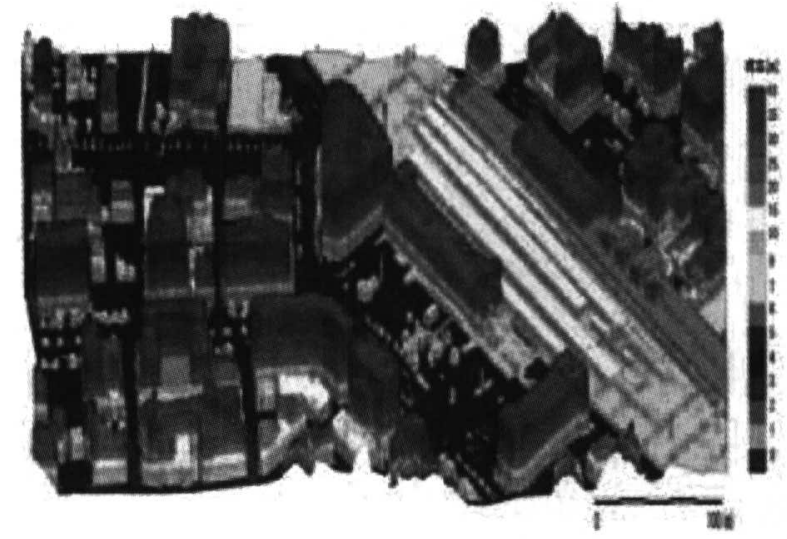

Fig. 3 Image of DEM and DSM

\section{3. 都市の可視化}

\section{1 都市空間占有率}

オリジナルデータと DEM 及び DSM を組み合わせる ことで都市の特徵を抽出することができる(特願 2003-413806)。その一例として都市空間の地物占有率を Fig. 4 示した。
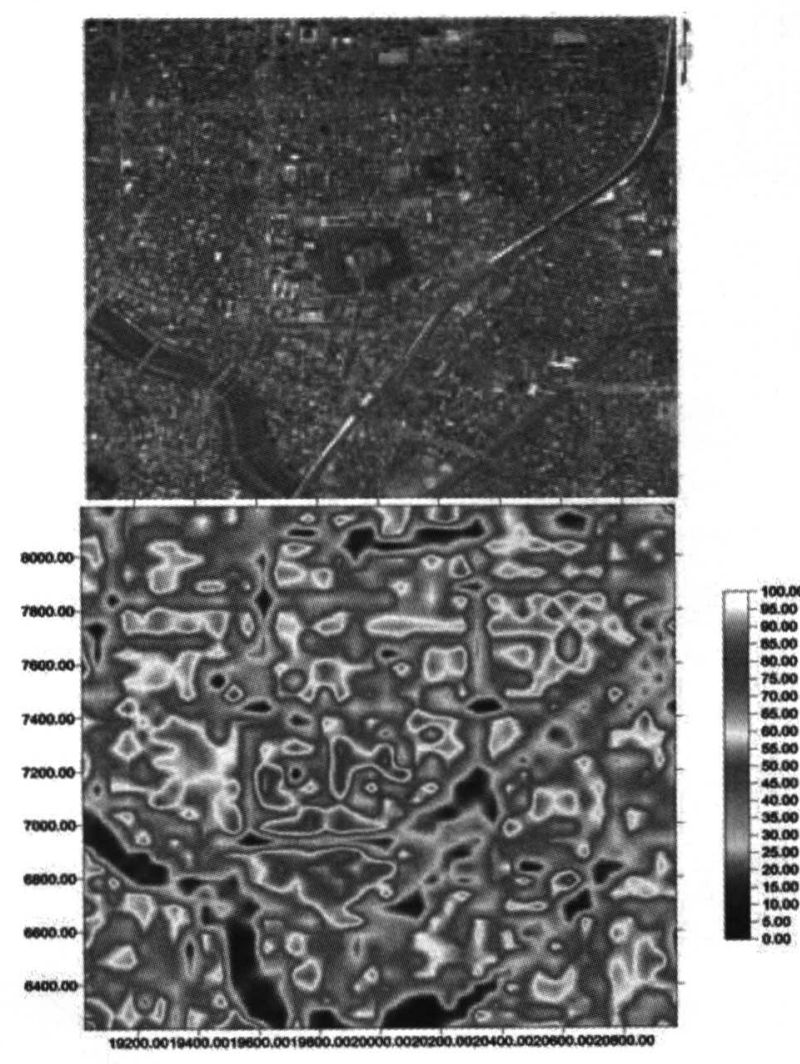

Fig. 4 Example of Space-Occupation Ratio
Fig. 4 は、十分に均一で密なオリジナルデータから、 $50 \mathrm{~m}$ メッシュ毎の DEM を作成し、地盤面から $5 \mathrm{~m}$ の高 さの地物占有率(\%)を示したものである。

地物の占有率が $20 \%$ 以下となっている青色部分は、都 市河川や主要道路や鉄道、グラウンドなどの空き地部分 と一致している。また、地物占有率が $50 \%$ ～ $60 \%$ となつ ている緑色から黄色の部分は一般住宅地、 $75 \%$ 以上の赤 色部分は駅前や官庁街のビル群の部分と一致している。

このようにオリジナルデータから得られる統計的な性 質をわかりやすく表現することで、都市の特徵を可視化 することができる。

\section{2 予想される浸水区域}

地物を除去した標高データ(DEM) と水理学的手法を 応用すると、堤防が決壊した場合に想定される浸水深と 浸水区域を予想することができる。Fig. 5 にその一例を 示した。浸水深や浸水区域はその都市の水害による潜在 的な被害ホテンシャルを可視化したものと考えることが できる。
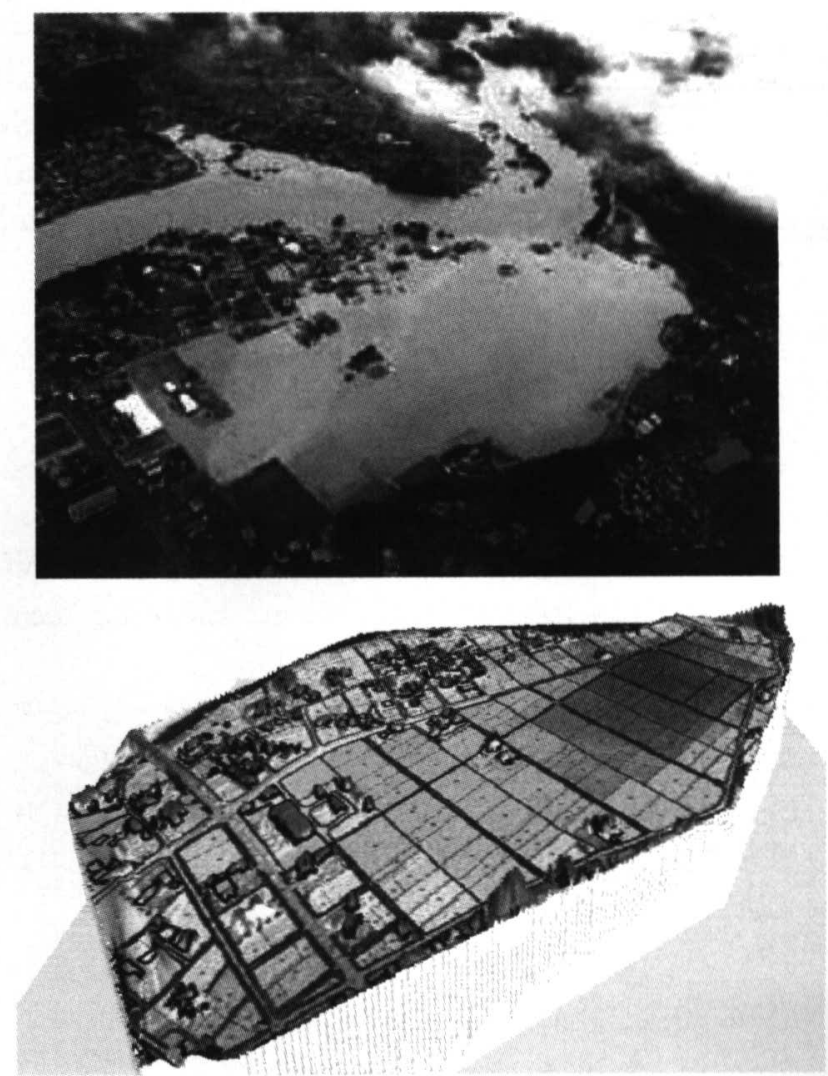

Fig. 5 Example of Forecasted Flood Area

\section{参 考 文 献}

1）図解「航空レーザ 測量ハンドブリ」（財）日本測量調查技術協 会

2）レーザープロロアイラデータを利用した洪水氾濫解析、日本りモートセシジ $\eta^{\prime}$ 学会第 28 回学術講演会, 2000

3）水防災への航空レーザ 計測技術の利用、平成 17 年度日本水

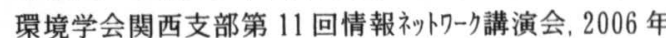

